\title{
IDENTIFIKASI JENTIK Aedes aegypti PADA BAK PENAMPUNGAN AIR MASYARAKAT JALAN SULTAN ALAUDDIN KELURUHAN MANGASA KECAMATAN TAMALATE MAKASSAR
}

\author{
Dewi Arisanti ${ }^{\mathbf{1})}$ Darmawaty Rauf $^{\mathbf{1})}$ Nurlaila $^{\mathbf{1})}$ \\ 1)Akademi Analis Kesehatan Muhammadiyah Makassar \\ Alamat Korespondensi: Harimuswarah@yahoo.co.id
}

\begin{abstract}
Abstrak
Penelitian ini berlatar belakang tentang maraknya kasus penyakit DBD yang disebabkan oleh virus Dengue yang ditularkan olehnyamuk Aedes aegypti. Jumlah penderita DBD di kota Makassar cenderung meningkat pada tahun 2004 (584 dan 2,05\%), tahun 2005 (832 dan 2,64\%), tahun 2006 (877 dan 1,93\%). Prevalensi DBD tertinggi di laporkan di Kecamatan Tamalate. Penelitian bertujuan untuk mengetahui adanya jentik Aedes aegypti pada bak penampungan air masyarakat Jalan Sultan Alauddin Kelurahan Mangasa Kecamatan Tamalate Makassar. Penelitian ini bersifat deskriptif, sampel yang digunakan air bak penampungan masyarakat Jalan Sultan Alauddin Kelurahan Mangasa Kecamatan Tamalate Makassar sebanyak 10 sampel. Hasil penelitian ini yang di temukan $3(30 \%)$ dari keseluruhan sampel positif jentik nyamuk Aedes agypti pada bak air penampungan masyarakat Jalan Sultan Alauddin Kelurahan Mangasa Kecamatan Tamalate Makassar.

Kata kunci: Aedes aegypti, Bak Penampungan Air, Jalan Sultan Alauddin
\end{abstract}

\section{PENDAHULUAN}

Penyakit Demam Berdarah Dengue (DBD) adalah suatu penyakit infeksi mendadak yang disebabkan oleh virus Dengue, yang ditularkan oleh gigitan nyamuk Aedes aegypti dan Aedes albopictus. Penyakit ini merupakan masalah kesehatan masyarakat yang serius di Indonesia, karena saat ini sudah memasuki hampir semua provinsi di Indonesia. Penyakit DBD tidak ditularkan langsung dari orang ke orang. Penderita menjadi infektif bagi nyamuk pada saat viremia, yaitu beberapa saat menjelang timbulnya demam hingga saat masa demam berakhir, biasanya berlangsung selama 3-5 hari.

Di Indonesia masih banyak daerah endemic penyakit DBD. Daerah endemik DBD pada umumnya merupakan sumber penyebaran penyakit ke wilayah lain setiap kejadian luar biasa (KLB) DBD umumnya dimulai dengan peningkatan jumlah khusus di wilayah tersebut. Untuk membatasi penyebaran penyakit DBD diperlukan pengasapan (fogging) secara massal, abatisasi massal, serta penggerakan pemberantasan sarang nyamuk (PSN) yang terus menerus (Widoyono, 2005.)

Pada tahun 2006, demam berdarah Dengue yang telah menjadi wabah nasional, juga melanda kota Makassar dan kabupaten lain di Sulawesi Selatan. Sebelumnya, DBD sudah menjadi masalah kesehatan dengan insiden yang meningkat setiap tahun dan resiko kematian yang tinggi. Jumlah penderita DBD di kota Makassar cenderung meningkat pada tahun 2004 (584 dan $2,05 \%$ ), tahun 2005 (832 dan 2,64\%), tahun 2006 (877 dan 1,93\%). Prevalensi DBD tertinggi di laporkan di kecamatan Tamalate (Sri Syatriani, 2015).

Angka kesakitan dan kematian DBD di berbagai negara sangat bervariasi dan tergantung pada berbagai macam faktor, seperti status kekebalan dari populasi, kepadatan vektor dan frekuensi penularan (seringnya terjadi penularan virus Dengue), prevelensi serotipe virus Dengue dan keadaan cuaca (Arbani Batubara, 2010).

Penyebaran penyakit ini meluas di seluruh dunia dengan angka kesakitan dan kematian lebih tinggi. Dalam satu tahun 
terdapat 250.000-500.000 kasus demam berdarah berdarah Dengue di seluruh dunia. Menurut WHO 2013 setiap tahun terdapat sekitar 500.000 kasus demam berdarah yang membutuhkan perawatan di rumah sakit dengan proses kasus terbanyak adalah pada anak-anak dan paling sedikit 2,5\% dari kasus mengalami kematian. Kasus demam berdarah Dengue dapat meningkat mencapai $20 \%$ pada tahun 2015. WHO memperkirakan terdapat paling sedikit 100 negara endemis deman berdarah dengue dan sekitar $40 \%$ dari populasi dunia $(2,5$ juta orang) yang berisiko merupakan penduduk wilayah tropis dan subtropics (Anonym 2014).

Demam berdarah dengue dipengaruhi oleh kondisi lingkungan yang buruk. Lingkungan yang buruk tersebut dapat berupa kondisi fisik perumahan yang tidak memenuhi syarat seperti ventilasi, suhu, kelembaban, dan penampungan air. Ketika cuaca berubah dari musim kemarau ke musim hujan sebagian besar permukaan dan barang bekas itu menjadi sarana penampung air hujan. Bila di antara tempat atau barang bekas itu berisi telur maka dalam waktu singkat akan menetas menjadi larva aedes aegypti yang dalam waktu (9-12 hari) menjadi nyamuk dewasa (Supartha, 2008).

Berbagai upaya telah dilakukan untuk menekan laju penularan penyakit DBD di masyarakat. Untuk mencapai tujuan ini, pengendalian kepadatan populasi vektor DBD mendapat perhatian yang besar.

Berdasarkan uraian diatas, peneliti tertarik melakukan penelitian mengenai hubungan jenis tempat penampungan air positif larva Aedes aegypty dengan kejadian demam berdarah dengue di Jl.Sultan Alauddin Kelurahan Mangasa Kecamatan Tamalate Makassar, dengan tujuan untuk mengetahui ada tidaknya jentik nyamuk dibak penampungan masyarakat kelurahan Mangasa kecamatan tamalate Makassar. Adapun manfaat sebagai sumber informasi bagi masyarakat khususnya warga kelurahan mangasa kecamatan tamalate.

\section{METODE PENELITIAN}

Alat dan Bahan

Alat yang digunakan adalah kaca objek, glass sampel, kain kasa, mikroskop, kaca tutup, pipet tetes, senter, saringan teh.

Bahan yang digunakan adalah air penampungan yang mengandung jentik nyamuk yang diambil pada bak penampungan air.

\section{Prosedur Penelitian}

\section{Teknik Pengambilan Sampel}

Teknik pengambilan sampel pada penelitian ini adalah secara random sampling. Larva (jentik) diambil pada tempat penampungan dan dimasukkan dalam glass penampungan atau toples yang ditutup dengan kain kasa.

\section{Identifikasi Larva (Jentik) Nyamuk}

Larva (jentik) diambil dengan menggunakan pipet tetes diletakkan di atas objek glass dan tutup dengan kaca penutup. Kemudian periksa secara mikroskopik dengan menggunakan lensa objective pembesaran 10x.

\section{Analisis Data}

Data dari penelitian ini akan diolah secara deskriptif dan disajikan dalam bentuk tabel.

\section{HASIL DAN PEMBAHASAN}

Berdasarkan hasil pemeriksaan di laboratorium Parasitologi Analis Kesehatan Muhammadiyah Makassar dengan 10 sampel air bak penampungan Masyarakat Jalan Sultan Alauddin Kelurahan Mangasa Kecamatan Tamalate Makassar diperoleh hasil ditunjukkan pada table 1 .

Tabel 1. Hasil Pemeriksaan Jentik Aedes aegypi

\begin{tabular}{|c|c|c|}
\hline No. & $\begin{array}{c}\text { Kode } \\
\text { Sampel }\end{array}$ & Hasil Pemeriksaan \\
\hline 1 & A & Aedes aegypti \\
\hline 2 & B & Aedes aegypti \\
\hline 3 & $\mathrm{C}$ & Negatif \\
\hline 4 & $\mathrm{D}$ & Negatif \\
\hline 5 & $\mathrm{E}$ & Negatif \\
\hline 6 & $\mathrm{~F}$ & Negatif \\
\hline 7 & G & Aedes aegypti \\
\hline 8 & $\mathrm{H}$ & Negatif \\
\hline
\end{tabular}




\begin{tabular}{|c|c|c|}
\hline 9 & I & Negatif \\
\hline 10 & $\mathrm{~J}$ & Negatif \\
\hline
\end{tabular}

mikroskopis diperoleh jentik nyamuk Aedes aegypti pada tiga bak penampungan dari 10 bak penampungan air di Jl. Sultan Alauddin yang diperiksa.

Penelitian yang dilakukan merupakan penelitian deskriptif yang bertujuan untuk menggambarkan keadaan atau mendapatkan keterangan tentang keberadaan jentik Aedes aegypti. Dari hasil penelitian di atas terdapat sampel bak penampungan air masyarakat Jalan Sultan Alauddin Kelurahan Mangasa Kecamatan Tamalate Makassar yang diteliti dari 10 masyarakat yang menggunakan bak penampungan air terdapat 3 positif sampel jentik Aedes aegypti, dan sampel Negatif terdapat 7.

Adanya temuan jentik Aedes aegypti menunjukkan adanya peluang timbulnya wabah demam berdarah, berdasarkan pengamatan dalam penelitan pada bak penampungan air masyarakat yang ditemukan jentik nyamuk Aedes aegypti.

Upaya pencegahan terhadap
penyakit DBD dilakukan dengan memutus rantai penularan dengan jalan memutus siklus hidup nyamuk Aedes aegypti dengan cara program pemerintah yaitu gerakan 3M (menguras, menutup, menimbun), kepada masyarakat adapun upaya lain yang dapat dilakukan dengan pengasapan menggunakan melathion untuk memberantas nyamuk dewasa, memberikan bubuk abate pada tempattempat penampungan untuk membunuh jentik dan telur, menggunakan kelambu saat tidur, menyemprot dengan insektisida, menggunakan lotion anti nyamuk, memasang obat anti nyamuk, memeriksa jentik nyamuk secara berkala sesuai kondisi setempat.

Untuk menekan peningkatan penyakit yang ditularkan oleh nyamuk Aedes aegypti perlu ada partisipasi oleh semua komponen dalam memberantas sarang nyamuk, di mana sering dilakukan penyuluhan-penyuluhan tentang pemberantasan sarang nyamuk Aedes aegypti dan bahaya penyakit DBD di masyarakat, baik langsung dari petugas kesehatan maupun melalui mesjid-mesjid yang ada di wilayah jalan sultan alauddin kelurahan mangasa kecamatan tamalate Makassar sehingga kasus DBD dapat diatasi sekecil mungkin.

Bak penampungan air sangat berpotensi untuk menjadi tempat perindukan nyamuk Aedes aegypti, hal disebabkan karena bak penampungan yang lembab, gelap, terlindung dari sinar matahari langsung, khususnya bak penampungan yang besar susah dikuras.

\section{KESIMPULAN}

Dari hasil pemeriksaan 10 sampel air bak penampungan masyarakat Jalan Sultan Alauddin Kelurahan Mangasa Kecamatan Tamalate Makassar dari 10 sampel terdapat 3 positif jentik Aedes agypti.

\section{SARAN}

1. Diadakan penyuluhan secara rutin oleh petugas penyuluhan dinas kesehatan bekerja sama dengan instansi terkait tentang pencegahan dan pemberantasan nyamuk Aedes aegypti dengan program 3M (Menguras, menutup, menimbun).

2. Memberikan bubuk abate pada tempat penampungan masyarakat Jalan Sultan alauddin Kelurahan Mangasa Kecamatan Tamalate Makassar.

3. Memperbaiki sanitasi lingkungan seperti mengajak masyarakat untuk berprilaku hidup bersih dengan harapan dapat menjaga dan meningkatkan kesehatan Masyarakat.

\section{DAFTAR PUSTAKA}

Anonym. 2014. Pedoman pengendalian nyamuk aedes aegypi.diakses pada tanggal 14 juni 2016. Diunduh dari (http;///books.goegle.co.id).

Azzaluddine. 2009. Demam berdarah dengue. (http;///blogspot). diakses pada tanggal 1 mei 2016.

Batubara, A. 2010. Faktor fakor yang mempengaruhi demam berdarah dengue (DBD) pada masyarakat di wilayah kerja puskesmas mandala kecamatan medan Tembung (Skripsi). Medan: Universitas Sumatera Utara. 
Genis G, 2008. Demam berdarah.Yogyakarta: B-first.

Gandahusada. 2008. Parasitologi Kedokteran Edisi Ketiga. Jakarta: FKUI.

Marfu'ah. 2010. Identifikasi jentik aedes aegypti (KTI). Makassar: Analis kesehatan muhammadiyah Makassar.

Soegeng, S. 2006. Demam Berdarah Dengue Edisi Kedua. Surabaya: Airlangga University Pres.

Sri, S. 2009. Partisipasi Masyarakat Menanggulangi Demam Berdarah Dengue di Kecematan Rappocini Kota Makassar. Jurnal Kesehatan Masyarakat Nasional 3: (5).

Supartha, 2008. Pengendalian terpadu Vetor virus deman berdarah dengue,aedes aegipti dan aedes albopictus (Skripsi). Bali: Universitas Udayana Denpasar.

Wahono, TD. 2010 Demam Berdarah Dengue. Diunduh di www.LitbangDepkes.go.id.

Widoyono. 2005. Penyakit Tropis Epidemiologi, Penularan, Pencegahan \& Pemberantasannya' Edisi Pertama Jakarta: Penerbit Erlangga.

Yatim, F. 2007. Macam-macam penyakit Menular dan Pencegahannya Edisi Pertama. Jakarta: Pustaka Obor Populer. 